\title{
Problems of exemption from criminal liability for restricting competition
}

\author{
Andrey Viktorovich Sarubin*
}

Saint Petersburg Law Institute (Branch) of the University of Prosecutor's Office of the Russian

Federation, the Department of Criminal Law, Criminology and Penal Law, Saint Petersburg, Russia

\begin{abstract}
The article considers the problems of exemption from criminal liability for restricting competition (Art. 178 of Criminal Code of the Russian Federation). The criminal legislation of Russia and the practice of its application in terms of exemption from liability for restriction of competition are analysed. It is thought that the main objectives of the criminal-law prohibitions contained in Chapter 22 of the Criminal Code of the Russian Federation, is to ensure the criminal-legal protection of economic relations, preventing the growth of crimes that threaten the development of financial institutions of the state. Purpose of work: Identify problems of exemption from criminal liability for restricting competition in the modern practice of preliminary investigation and court, and propose ways to improve the criminal law on the exemption from criminal liability for restricting competition. Methods. The methodological basis of the research was the general dialectical method of scientific knowledge, which has a universal character, as well as methods of logical deduction, induction, cognitive methods and techniques of observation, comparison, analysis, synthesis and description, formally logical. Results. The research revealed the problems of application of the criminal law on the exemption from criminal liability for restriction of competition and suggested ways to improve paragraph 3 of the notes to the Art. 178 of Criminal Code of the Russian Federation, providing for the possibility of exemption from criminal liability for restricting competition.
\end{abstract}

Keywords: exemption from criminal liability, crimes in the sphere of economic activity, restriction of competition

\section{Introduction}

An important means of ensuring Russia's economic security in today's unstable global economic environment is to strengthen the economic sovereignty of the Russian Federation.

A very important indicator of the criminal-law regulation of economic relations is the criminal-law protection of competition and ensuring competitive market relations. A similar position is held by foreign scholars [1].

\footnotetext{
*Corresponding author: Sarubin1@yandex.ru
} 
Paragraph 57 of the National Security Strategy of the Russian Federation, approved by Presidential Decree No. 683 of December 31, 2015, states that "the negative impact on economic security has, among other things, an increase in unfair competition" [2].

A government bill is currently before the State Duma that would increase the penalties for Art. 178 of Criminal Code of the Russian Federation [3, p. 18-20].

In 2019, the Federal Antimonopoly Service of Russia initiated 944 cases on anticompetitive agreements, including 424 cases on cartels (an increase of $15 \%$ compared to 2018). More than $87 \%$ of cartel cases are bid-rigging [4].

At the same time, according to the data of Federal State Institution "Main Information and Analysis Center of Ministry of Internal Affairs of Russian Federation" (Form 495 section 1). In January-December 2020, 18 crimes were detected according to Art. 178 of Criminal Code of the Russian Federation, which is 3 more crimes than in 2019 (15 crimes).

\section{Results and discussion}

The author agrees with the opinion of Egorova that in the case of finding signs of a crime should be applied "a very strict model of antimonopoly responsibility in the form of bringing cartel participants to criminal liability on the basis of Art. 178 of Criminal Code of the Russian Federation" [5, pp. 33-36]. In this regard, it appears that within the framework of the criminal-legal protection of economic relations "in the sphere of ensuring equality of subjects of economic activity, ensuring equal opportunities to carry out business activities in a competitive environment" [6, p. 157].

The crimes listed are as follows in Art. 76.1 Criminal Code of the Russian Federation in Art. 28.1 of the Russian Federation Code of Criminal Procedure have a clear economic orientation (including norms on violation of copyright and inventive rights, providing for material damage) and are addressed mainly to entrepreneurs [7, pp. 9-13].

Federal Law No. 45-FZ of March 08, 2015 "On Amendments to Article 178 of the Criminal Code of the Russian Federation" The text of Part II of the Act was substantially changed as the text of Part II of the Act. 1 Art. 178 of Criminal Code of the Russian Federation, which is more consistent with the global experience of responsibility for violations of antitrust laws [8, p. 42], as well as the text of paragraph 3 of the notes to the Art. 178 of Criminal Code of the Russian Federation [9].

Many of the issues of determining damage caused by a crime under Art. 178 of the Criminal Code of the Russian Federation in practice have not found a unified approach. At the same time, in the foreign literature among the main methods of determining damages are taken into account, for example, the comparison of prices during the cartel period with the prices of the relevant market without signs of cartel collusion [10, p. 222.]

In the science of criminal law, attention was drawn to the issues of correlation between the application of part 2 of Art. 76.1 of the Criminal Code of the Russian Federation and para. The criminal law scholarship has paid attention to the issues of correlation between the application of part 2 of Art. 178 of Criminal Code of the Russian Federation. For example, N. G. Ivanov rightly points out that "In the event that the subject has not had time to fulfill the conditions contained in note 3 of Art. 178 of the Criminal Code (did not have time, for example, to be first in line for a communication), then he can use the imperatives of Art. 76.1 of the Criminal Code" [11, pp. 43-48].

Following paragraph 15.1 of the Resolution of the Plenum of the Supreme Court of the Russian Federation "On application by the courts of the legislation governing the grounds and procedure for exemption from criminal responsibility" from 27.06.2013 No. 19 (revised on 29.11.2016), "if a person who has committed a crime of small or medium gravity in the field of entrepreneurial and other economic activity has not performed all or not in full the actions prescribed by article 76.1 of the Criminal Code of the Russian Federation, his 
application to terminate criminal prosecution on grounds provided by articles 75,76 or 76.2 of the Criminal Code of the Russian Federation, may be granted by the court, provided that the requirements contained in the said norms are met" [12]. It seems to be necessary to extend this rule to the ratio of articles 75, 76, or 76.2 of the Criminal Code of the Russian Federation with paragraph 3 of the notes to the Art. 178 of Criminal Code of the Russian Federation.

According to Esakov, the subject of the crime under Art. 178 of the Criminal Code of the Russian Federation may be its head, or another person from among those specified in Note 1 to Art. 201 of the Criminal Code of the Russian Federation, or the actual head of the organization. All of them in the context of restriction of competition to be held liable must be united by the sign of the ability to force a legal entity to act in a certain way, i.e. to conclude a cartel agreement [13, pp. 140-152].

However, when committing the crime in question with destruction or damage to another's property or with the threat of destruction or damage (item "b" part 2 of Art. 178 of the Criminal Code of the Russian Federation), as well as with the use of violence or with the threat of its application (part 3 of Art. 178 of the Criminal Code of the Russian Federation), it seems that the general subject of the crime (for example, committing the crime on hire) may also be held responsible.

Under paragraph 29 of the Resolution of the Plenum of the Supreme Court of the Russian Federation No. 48, dated November 30, 2017 "On judicial practice in cases of fraud, misappropriation and embezzlement" if persons performing the functions of the sole executive body or heads of the collective executive body (for example, the chairman of the board of a joint-stock company) or persons authorized by the head of a commercial organization took part in the conclusion between business entities-competitors limiting competition agreement (cartel), prohibited in accordance with the antimonopoly legislation of the Russian Federation, such act 178 of the Criminal Code of the Russian Federation.

In such a case, paragraph 3 of the notes to Art. 178 of the Criminal Code of the Russian Federation. In the case of committing by a person the crimes provided for by parts 2,3 of Art. 178, in respect of him, can be applied exclusively item 3 of the note to this article [14, p. 40-42]. This is not a sufficient reason to apply the provisions of paragraph 3 of the notes to Art. 178 of the Criminal Code of the Russian Federation in respect of a person who participated in the commission of a crime only in terms of destruction or damage to another's property or the threat of its destruction or damage, in the absence of signs of extortion (paragraph "b" of part 2 of Art. 178 of the Criminal Code of the Russian Federation), and also by the use of violence or the threat of its use (part 3 of Art. 178 of the Criminal Code of the Russian Federation) 178 of the Criminal Code of the Russian Federation, as this person took part only in one of the stages of committing a crime and caused harm or damage to a certain person, but not to the entire object of the crime - social relations in the sphere of economic activity.

According to Volzhenkin "In such cases, there is an encroachment not only on the established order of economic activity, but also on the person and (or) property relations" [15, p. 429]. Since the crime under Art. 178 of the Criminal Code of the Russian Federation is a continuing one (according to foreign researchers' estimates it can last for about six years $[16$, P. 512]) in its commission may take part persons who joined the common criminal activity only temporarily. Thus, it seems unfair to apply to a person who has committed a crime, paragraph 3 of the notes to Art. 178 of the Criminal Code of the Russian Federation after he has compensated for the damage caused by this crime or otherwise made amends for the harm caused.

In this situation, it is believed that it would be more correct to provide for the possibility of exemption from criminal liability in accordance with paragraph 3 of the notes to Art. 178 of the Criminal Code of the Russian Federation, if the person will compensate for the damage 
caused by this crime or otherwise make amends for the harm caused for the entire period of his participation in the crime in question.

There has already been a discussion in criminal law scholarship about the shortcomings of Art. 3 of the notes to Art. Criminal Code of the Russian Federation, expressed in inaccurate indication of the consequences of the committed crime. So, Ustinova writes: “... the disposition of the article says only about causing damage, and in Note 3 appears a new word harm" [17, p. 110-117].

Supporting the author, it should be emphasized that the current wording of the studied note does not distinguish as a consequence causing major damage or particularly major damage to citizens, organizations or the state, which arose as a result of a violation of antimonopoly legislation and that harm or damage that arose as a result of destruction or damage to property of others ( paragraph "b" part 2 Art. 178 of Criminal Code of the Russian Federation), and as a result of violence or a threat to use it against a citizen (part 3 Art. 178 of Criminal Code of the Russian Federation). Let us believe that the amount of damage or harm caused will vary significantly.

The explanatory note "On Amendments to Article 178 of the Criminal Code of the Russian Federation and Certain Legislative Acts of the Russian Federation" of 16.04.2013 states that "the proposed changes to paragraph 3 of the notes to Article 178 of the Criminal Code of the Russian Federation clarify the criteria and conditions of exemption from criminal liability of persons who have committed a crime under this article, and are aimed at improving the effectiveness of the investigation of cartel agreements and creating additional guarantees of suppression of the implementation of such agreements at the stage of their conclusion" [18]. In the case under consideration, encouragement is the result that stimulates positive post-criminal behaviour of the person [19, pp. 97-101].

However, it seems manifestly unfair to impose damages on one cartelist who chooses to cooperate with the state. in such circumstances, the effect of paragraph 3 of the notes to article 178 of the Criminal Code of the Russian Federation, aimed at identifying and proving cartel activity is either complicated [20, p. 524], or inapplicable.

\section{Conclusion}

Thus, as a result of the study, paragraph 3 of the notes to Art. 178 of the Criminal Code of the Russian Federation, we propose to amend it to read as follows: "A person who has committed a crime provided for by this article, in the absence of evidence of a crime provided for by paragraph "b" of part two as well as part three of this article, shall be exempt from criminal liability if he voluntarily reported the crime to the federal antimonopoly service of Russia or to the authorities entitled to institute criminal proceedings, actively assisted in the detection and (or) investigation of the crime, compensated the damage caused by the crime in full or otherwise made amends for the damage caused".

The author also suggests that it is necessary to delete the words "... part one of Art. 178, ..." from the text of Art. 2 Art. 178 of the Criminal Code of the Russian Federation.

\section{References}

1. Competition Law of the European Community (Kluwer Law International, Van Bael \& Bellis, 2005)

2. On the National Security Strategy of the Russian Federation: Presidential Decree of 31.12.2015 No. 683. Access from the reference system "ConsultantPlus"

3. A.V. Kurakin, A.N. Sukharenko, Russian Justitia, 11, 18 (2020) 
4. Federal Antimonopoly Service of Russia. Access date: January 01, 2021. Available: https://fas.gov.ru

5. M.A. Egorova, Preprinimatelskoe Pravo, 3, 33 (2020)

6. V.I. Tyunin, Prestupleniya v sfere ekonomicheskoy deyatelnisti [Crimes in the field of economic activity: textbook] (Yurlitinform Publ., Moscow, 2012)

7. N.N. Apostolova, Magistrate Judge, 7, 9 (2020)

8. A. Bhattacharjea, U.B. Sinha, International Journal of Industrial Organization, 41, 42 (2015). https://doi.org/10.1016/j.ijindorg.2015.05.003.

9. O popravkakh k statie no. 178 UK RF [On Amendments to Article 178 of the Criminal Code of the Russian Federation: Federal law of 08.03.2015 No. 45-FZ]. Access from the reference system "ConsultantPlus"

10. W.H. Boshoff, South African Journal of Economics, 83(2), 220 (2015)

11. N.G. Ivanov, Criminal Judicial Proceeding, 1, 43 (2017)

12. Postanovlenie Plenuma Verkhovnogo suda RF [Resolution of the Plenum of the Supreme Court of the Russian Federation "On the application by the courts of the legislation regulating the grounds and procedure for exemption from criminal responsibility", 27.06.2013, No. 19 (ed. from 29.11.2016). Access from the reference system "ConsultantPlus"

13. G.A. Esakov, Zakon, 8, 140 (2019)

14. V.V. Vlasenko, Zakonnost, 3, 40 (2017)

15. B.V. Volzhenkin, Prestupleniya v sfere ekonomicheskoy deyatelnosti po ugolovnomu pravu Rossii [Crimes in the field of economic activity under the criminal law of Russia] (Izdatelskiy Tsentr Press Publ., Saint Petersburg, 2007)

16. M. Kallioinen, Business History, 57(4), 512 (2015). http://hdl.handle.net/10.1080/00076791.2014.929114

17. T.D. Ustinova, Actual Problems of Russian Law, 7, 110 (2016)

18. Poyasnitelnaya zapiska k proektu Federalnogo zakona [Explanatory Note "To the Draft Federal Law "On Amendments to Article 178 of the Criminal Code of the Russian Federation and some legislative acts of the Russian Federation" from 16.04.2013]. Access from the reference system "ConsultantPlus".

19. O.G., Solovyov, A.A Knyazkov, Laws of Russia: Experience, Analysis, Practice, 8, 97 (2019)

20. K. Hüschelrath, Journal of European Competition Law and Practical, 1(6), 522 (2010). https://doi.org/10.1093/jeclap/lpq047 